\title{
Modelling of phosphate enrichment and trophic status of Sipin Lake Jambi using TSI Carlson method
}

\author{
Ira Galih Prabasari ${ }^{1, *}$, Hutwan Syarifuddin ${ }^{2}$, and Damris Muhammad ${ }^{1}$ \\ ${ }^{1}$ Engineering Faculty, Jambi University, 36361 Jambi, Indonesia \\ ${ }^{2}$ Graduate Program of Environment Science, Jambi University, 36361 Jambi, Indonesia
}

\begin{abstract}
Floating fishery net (keramba) activity in Sipin Lake Jambi has increased significantly in the last decade. This intensive fishery results in enrichment of phosphate due to the application of fish feeding and induces eutrophication. The objectives of this study are to determine phosphate enrichment, the trophic status using TSI Carlson method and to propose a model of phosphate enrichment in the lake water. TSI Carlson is a method to determine the trophic status condition in the water body. Composite water samples were collected at up-, downstream and middle of the lake. Total phosphate content, chlorophyl-a, and brightness were measured. The results show that the average of total phosphate, chlorophyl-a, and brightness of the lake water are $0.0505 \mathrm{mg} / \mathrm{L}, 5.86 \mu \mathrm{g} / \mathrm{L}$ and $58 \mathrm{~cm}$, respectively. These figures indicate that fishery net activity has induced eutrophication with phosphate enrichment of $9.65 \mathrm{~T} / \mathrm{yr}$. A proposed TSI Carlson model estimates the TSI value would be 61.79 within next ten years with phosphate enrichment of $12.04 \mathrm{~T} / \mathrm{yr}$. Application of double fishery nettings (keramba) would be expected to reduce these figures and the risk of eutrophication in the lake.
\end{abstract}

\section{Introduction}

Developing aquaculture in a lake such as fishery activity using floating fishery nets potentially improves social welfare. However, this is usually followed by enrichment of phosphate in water body as a result of the application of fish feeding and induces algae bloom/ eutrophication. Sometimes, phosphate concentrations in lake water exceed eutrophication level of $0.035-0.1$ $\mathrm{mg} / \mathrm{L}$ [1]. This affects physical appearances of lake water such as muddy and stinks thereby disrupting local community activities.

Sipin Lake located at Jambi city of Jambi Province is surrounded with a quite dense population of three kelurahan (Legok, Buluran Kenali, and Sungai Putri) with about 2,500 people per square $\mathrm{km}$. There are offices, hospital, and residence area in the south of the lake and Batanghari River in the north. In the east, there is a hotel and residence areas and only residence area in the west. The lake area about $227 \mathrm{Ha}$ and water depths of 2-6 meters are an ideal place for fishery activity. Three tributaries flow into the lake [4] with only one output to Batanghari River. Phosphate originating from these flows is ignored in this study but floating fishery net is the major source of phosphate in the lake water [5]. Based on the data reported by Local Environmental Institution (BLH) within the last two years (2013 and 2014) showed that the average of total phosphate concentration in the lake water is above eutrophication limits [4]. This indicates that the increasing number of floating fishery nets in the lake results an eutrophication.
In year 2013 annual fish production are 900 tons and number of floating fishery net are 4,348 units. With $10 \%$ increase in the fishery net and $5 \%$ fish production, it is estimated an increase of 100-ton annual fish production within next 5 years [3]. This means that fish feeding material released to the lake system also increases. It is known that $150-200 \mathrm{~kg}$ feeding material is needed for every 1000 -fish for every 3 -month. Since the feeding materials contain $1.2 \%$ of phosphate [2] and $41 \%$ of it is released into water, it is estimated that approximately 35 tons of phosphate are released into Sipin Lake water each year.

High concentrations of phosphate in the water affect the trophic status of the lake such as water productivity, nutrient enrichment, brightness and some biological activities in the water. The objectives of this study are to determine phosphate enrichment and the trophic status of the lake and to propose a model of phosphate enrichment in the lake system. The latter is expected to be useful for the local government as an anticipative policy of phosphate enrichment in Sipin Lake later. A model of phosphate enrichment within next 10-year was developed using Powersim 2.5.

\section{Research methods}

This study was conducted in January to April 2015. The samples were collected at up-, downstream, and the middle of the lake on 28th January, 6th February, and 17th March. Water sample collection and brightness measurements were conducted on summer of January

\footnotetext{
* Corresponding author: iragalih@gmail.com
} 
and February, but on March the rain is higher than the previous ones. Although this study does not provide data for the whole year, however, the data could be used as an estimation of the whole year as no significant different in phosphate concentration and brightness of these twoperiod sampling $(\mathrm{p}>0,05)$. This is also supported by a report from Local Environmental Institution (BLHD) shows there is no significant variation of phosphate and brightness of Sipin lake water [4]. Sampling location is shown in Figure 1.

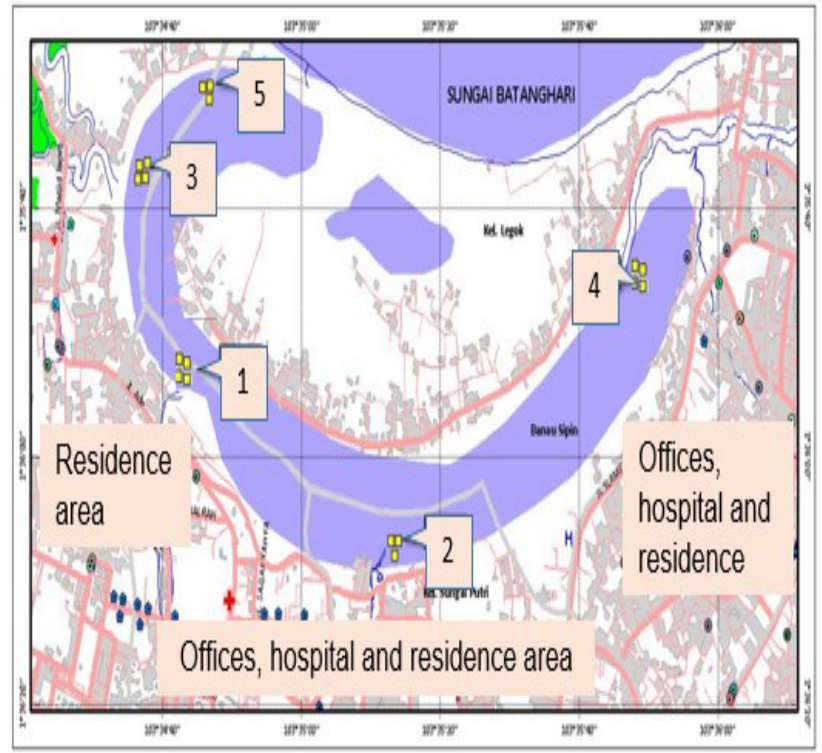

Fig. 1. Sampling point location

1. Kambang River - Upstream (01035'51.4"S and 10334'39.6”'E)

2. Putri River - Upstream (0136'09.6"S and $\left.103^{\circ} 35^{\prime} 13.9^{\prime \prime} \mathrm{E}\right)$

3. Kenali Besar River - Upstream (01'35'40.4'S and 10334'34.9'"E)

4. Downstream $\left(01^{\circ} 35^{\prime} 34.1^{\prime \prime} \mathrm{S}\right.$ and $\left.103^{\circ} 36^{\prime} 02.6^{\prime \prime} \mathrm{E}\right)$

5. Pandan Island - Middle (01³6'02.5”S and 103'35'03.2'E)

6. Buluran - Middle (01'36'31.1'S and 103'34'37.7'E)

Total phosphate concentration was analyzed using spectrophotometer UV-Vis Pharo 300 with $\lambda=880 \mathrm{~nm}$, intercept 0.0331 and slope 0.6752 with regression line of $\mathrm{Y}=0.6752+0.0331$. Water brightness was measured using Secchi Disk and chlorophyl-a was calculated based on total phosphate concentration using equation 5 . Chlorophyl-a is an indicator of the biological condition in the lake water. All measurements in the field were conducted in three replications.

Trophic status of the lake was calculated using TSI Carlson classification given in Table 1. Trophic Status Index (TSI) of the lake was calculated by measuring brightness of the lake water using Secchi Disk (TSISD), biological condition using chlorophyl-a indicator (TSICHL) and total phosphate concentration (TSITP) measured in the lake water.
Table 1. TSI Carlson index.

\begin{tabular}{|c|c|c|c|c|}
\hline TSI & $\begin{array}{c}\text { Status } \\
\text { Trophic }\end{array}$ & $\begin{array}{c}\text { Brightness } \\
(\mathbf{m})\end{array}$ & $\begin{array}{c}\text { TP } \\
(\mathbf{m g} / \mathbf{m 3})\end{array}$ & $\begin{array}{c}\text { Chl-a } \\
(\mathbf{m g} / \mathbf{m} 3)\end{array}$ \\
\hline 1 & Oligotrophic & 64 & 0.75 & 0.042 \\
\hline 10 & Oligotrophic & 32 & 1.5 & 0.012 \\
\hline 20 & Oligotrophic & 16 & 3 & 0.34 \\
\hline 30 & Oligotrophic & 8 & 6 & 0.94 \\
\hline 40 & Oligotrophic & 4 & 12 & 2.64 \\
\hline 50 & Mesotrophic & 2 & 24 & 6.4 \\
\hline 60 & Eutrophic & 1 & 48 & 20 \\
\hline 70 & Eutrophic & 0.5 & 96 & 56 \\
\hline 80 & Eutrophic & 0.25 & 192 & 154 \\
\hline 90 & Eutrophic & 0.12 & 384 & 427 \\
\hline 100 & Eutrophic & 0.062 & 768 & 1183 \\
\hline
\end{tabular}

As Mamatha reported [6] the classification of TSI Carlson index based on the following equations:

$$
\begin{gathered}
\text { TSID }=60-14.41 \ln (S D) \\
T S I C H L=9.81 \ln (C H L)+30.6 \\
T S I T P=14.42 \ln (T P)=4.15 \\
T S I=(T S I D+T S I C H L+T S I T P) / 3
\end{gathered}
$$

Where TSISD is TSI for Secchi Disk (m); TSICHL is TSI for klorofil-a $(\mu \mathrm{g} / \mathrm{l})$ and TSITP is TSI for Total phosphate $(\mu \mathrm{g} / 1)$.

Chlorophyl-a was calculated using total phosphate concentration as Beveridge equation [7] as below.

$$
C H L-a=0.416(P)^{0.675}
$$

In the water phosphorus originating from fish feeding is transformed into phosphate. The mathematical model for phosphate enrichment is given below.

$$
\begin{aligned}
& \text { Phosphate enrichment }=P U+P F-P D \\
& \text { Phosphate from } f \text { fishery net }=P W+P F C
\end{aligned}
$$

Where:

$\mathrm{PU}=$ Phosphate from up stream

$\mathrm{PF}=$ Phosphate from floating fishery net

$\mathrm{PD}=$ Phosphate from downstream 
PW $=$ Phosphate release to water

$\mathrm{PFc}=$ Phosphate in fish feces

Approximately $37.7 \%$ of phosphate is absorbed by fish, the remaining is released to water as residual feed and feces [7].

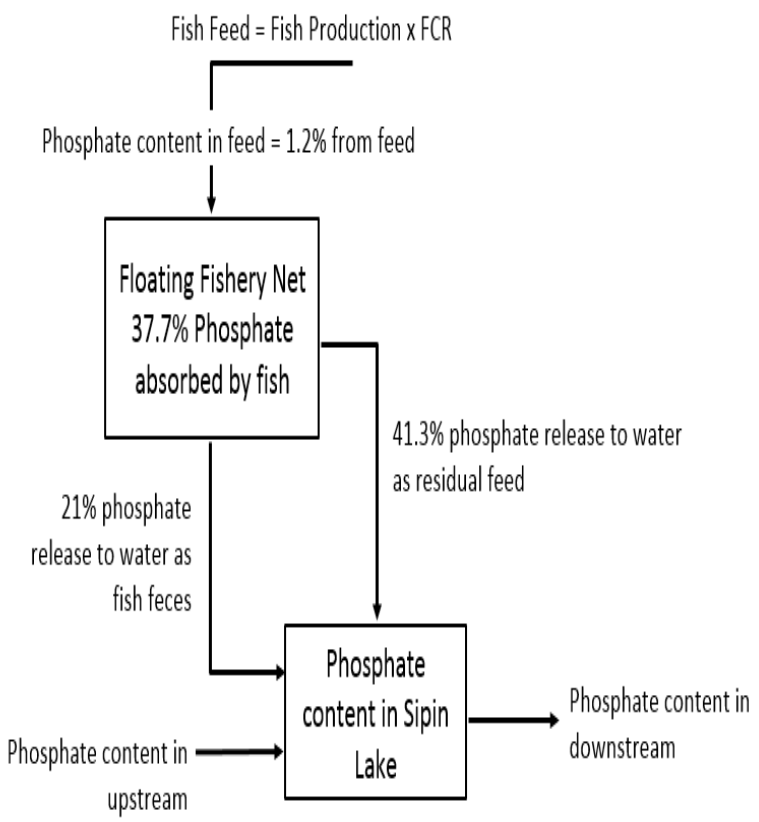

Fig. 2. Phosphorous enrichment empirical model.

\section{Result and discussion}

The analysis results of total phosphate shown in Table 2. From t-test, we know that the samples from each sampling point are not significantly different.

Table 2. Sampling location and total phosphate analysis result in $\mathrm{mg} / \mathrm{l}$.

\begin{tabular}{|c|c|c|c|}
\hline \multirow{2}{*}{$\begin{array}{c}\text { Sampling } \\
\text { point }\end{array}$} & \multicolumn{3}{|c|}{ Sampling date } \\
\cline { 2 - 4 } & $\mathbf{2 8 - 0 1 - 2 0 1 5}$ & $\mathbf{0 6 - 0 2 - 2 0 1 5}$ & $\mathbf{1 7 - 0 3 - 2 0 1 5}$ \\
\hline 1 & 0.166 & 0.166 & $<0.01$ \\
\hline 2 & 0.150 & 0.136 & 0.022 \\
\hline 3 & 0.062 & $<0.01$ & $<0.01$ \\
\hline 4 & 0.110 & 0.108 & $<0.01$ \\
\hline 5 & 0.056 & $<0.01$ & $<0.01$ \\
\hline 6 & 0.045 & $<0.01$ & $<0.01$ \\
\hline
\end{tabular}

Phosphate enrichment calculation based on total phosphate analysis, empirical model, and 2013 total fishery production. This calculation showed that phosphate enrichment in Sipin Lake is $9.65 \mathrm{~T} / \mathrm{yr}$
Table 3. Phosphate enrichment calculation

\begin{tabular}{|c|c|}
\hline Source of phosphate & $\mathbf{T} / \mathbf{y r}$ \\
\hline Phosphate from floating fishery net & 8.71 \\
\hline Phosphate from upstream & 3.37 \\
\hline Phosphate from downstream & 2.43 \\
\hline Phosphate enrichment & 9.65 \\
\hline
\end{tabular}

There are 2 areas for development of aquaculture in Sipin Lake, Pulau Pandan and Buluran area, the samples compiled from the two areas. Trophic status index calculation is shown in Table 4 and Table 5.

Table 4. Trophic status of Buluran area.

\begin{tabular}{|c|c|c|}
\hline Parameter & Data & TSI Carlson \\
\hline Total phosphate & $45 \mu \mathrm{g} / \mathrm{l}$ & 59.04 \\
\hline Brightness & $0.4 \mathrm{~m}$ & 73.20 \\
\hline Chlorophyl-a & $4.43 \mu \mathrm{g} / 1$ & 47.20 \\
\hline TSI Carlson Index & & 60.00 \\
\hline
\end{tabular}

TSI Carlson index of Buluran area is 60 which indicates the eutrophic level in the lake.

Table 5. Trophic status of Pandan Island.

\begin{tabular}{|c|c|c|}
\hline Parameter & Data & TSI Carlson \\
\hline Total phosphate & $56 \mu \mathrm{g} / \mathrm{l}$ & 62.19 \\
\hline Brightness & $0.76 \mathrm{~m}$ & 63.95 \\
\hline Chlorophyl-a & $6.29 \mu \mathrm{g} / 1$ & 48.64 \\
\hline TSI Carlson Index & & 58.26 \\
\hline
\end{tabular}

TSI Carlson index of Pulau Pandan is 58.26, indicates the eutrophic level in the lake.

To figure out the trophic status condition and phosphate enrichment for next 10 years, a modeling system is developed using Powersim 2.5. The modeling system has 3 sub-models.

Sub-model 1: phosphate enrichment. The input of this sub-model is fishery production and the output is Sipin Lake phosphate enrichment.

Sub-model 2: concentration of total phosphate. the output of sub-model 1 is input for sub-model 2. The conversion of phosphate enrichment in sub-model 1 into total phosphate concentration was calculated using morphological condition as depth, upstream, 
downstream, area, and volume of the lake. The output of this sub-model is total phosphate concentration in $\mathrm{mg} / \mathrm{l}$.

Sub-model 3: trophic status. the output of sub-model 2 is input for sub-model 3. In this sub-model, trophic status of the lake is calculated using total phosphate concentration from sub-model 2. Total phosphate concentration is used to calculate chlorophyl-a. The output of this sub-model is status trophic index.

All sub-model will build a modeling system of Sipin Lake's status trophic as shown in Figure 3.

From the modeling system, the figures of phosphate enrichment, total phosphate concentration and trophic status of Sipin Lake for next 10 years could be estimated as given in Table 6 . The target proposed by agriculture and fisheries department of Jambi province fish production would increase approx. 2\% per year in 2015 . This means that total phosphate enrichment and trophic status of the Lake also increase as shown in Figure 4. Table 6 and Figure 4 show that in the year 2023 phosphate enrichment, total phosphate concentration and trophic status index of the Lake increase 18.94\%, $15.64 \%$ and 61.79 , respectively. The latter indicates that the Lake would be in eutrophic condition.

Table 6. Sipin lake estimation condition for next 10 years.

\begin{tabular}{|c|c|c|c|c|}
\hline Year & $\begin{array}{c}\text { Fish prod. } \\
\text { (T/yr) }\end{array}$ & $\begin{array}{c}\text { TP } \\
(\mathbf{m g} / \mathbf{l})\end{array}$ & $\begin{array}{c}\text { Phosphate } \\
\text { enrichment } \\
(\mathbf{T} / \mathbf{y r})\end{array}$ & $\begin{array}{c}\text { Trophic } \\
\text { Status } \\
\text { Index }\end{array}$ \\
\hline 2014 & 909 & 0.0507 & 9.76 & 60.59 \\
\hline 2015 & 934 & 0.0518 & 10.01 & 60.73 \\
\hline 2016 & 959 & 0.0528 & 10.27 & 60.88 \\
\hline 2017 & 984 & 0.0539 & 10.52 & 61.01 \\
\hline 2018 & 1010 & 0.0549 & 10.77 & 61.15 \\
\hline 2019 & 1034 & 0.0560 & 11.02 & 61.28 \\
\hline 2020 & 1060 & 0.0571 & 11.28 & 61.41 \\
\hline 2021 & 1084 & 0.0581 & 11.53 & 61.54 \\
\hline 2022 & 1109 & 0.0592 & 11.78 & 61.67 \\
\hline 2023 & 1135 & 0.0601 & 12.04 & 61.79 \\
\hline
\end{tabular}

The model was validated using MAPE, MAD, MSD, and Durbin-Watson test. From the test, the value of MAPE, MAD, and MSD are lower than 5\%, indicates that the model doesn't have significant error. DurbinWatson test indicates that the model doesn't have autocorrelations from each equation.

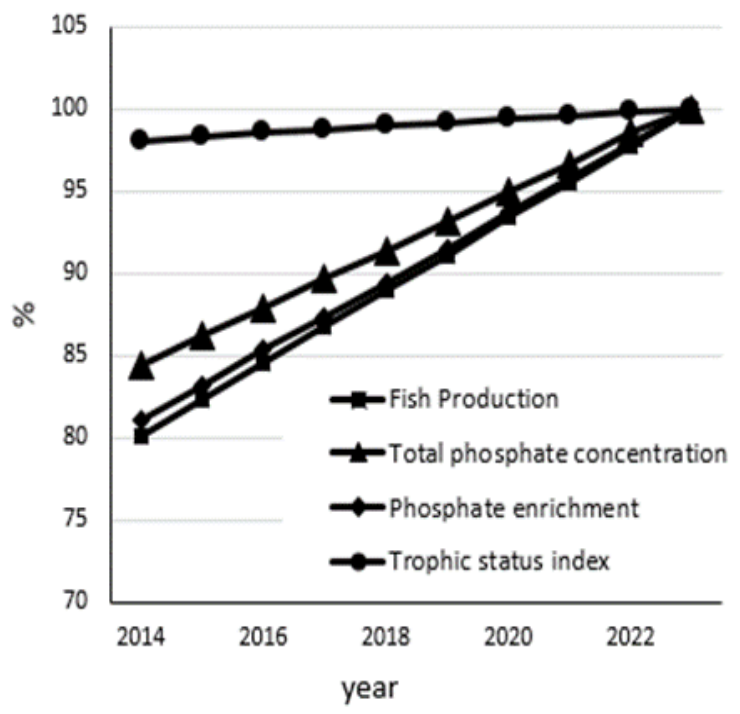

Fig. 4. Sipin Lake estimation condition for next 10 years

Some alternative policies that may be undertaken by the Local Government to reduce the risk of phosphate enrichment, total phosphate concentration and the trophic status increase in the Sipin Lake are discussed as follows.

1. Application of double floating fishery net. This system can cut nutrient in the water more than $90 \%$ since the system is combined with the fish culture outside the net. Application of double netting only reduces the nutrient to approximately $50 \%$ as reported in Waduk Sermo in 2009 [8]. Figure 5 shows reduction estimation in percent of phosphate enrichment, total phosphate concentration, and trophic status of Sipin Lake by applying double fishery netting. Figure 5 shows that in year 2015, total phosphate concentration and phosphate enrichment in lake water will be reduced $13.32 \%$ and $16.38 \%$ after 8 years application of double netting and trophic status of the Lake is mesotrophic level.

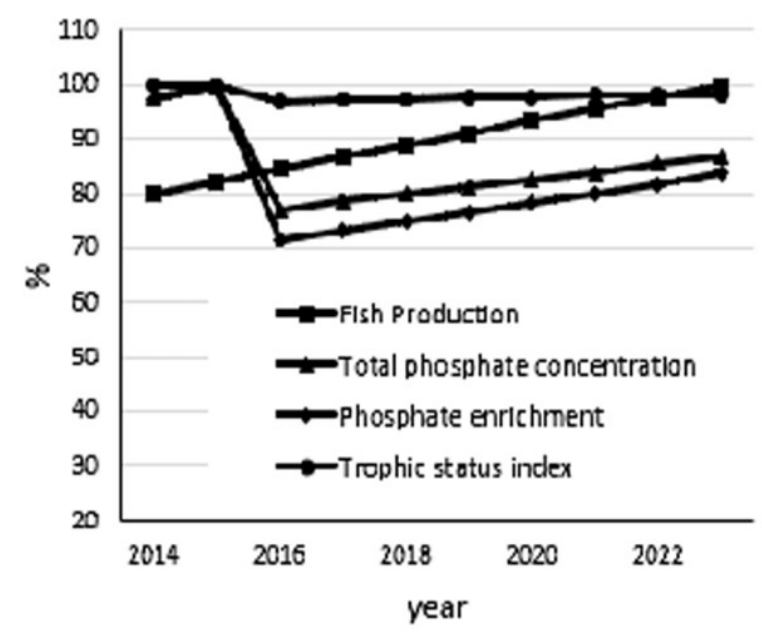

Fig. 5. Sipin Lake estimation condition by applying double floating fishery net 


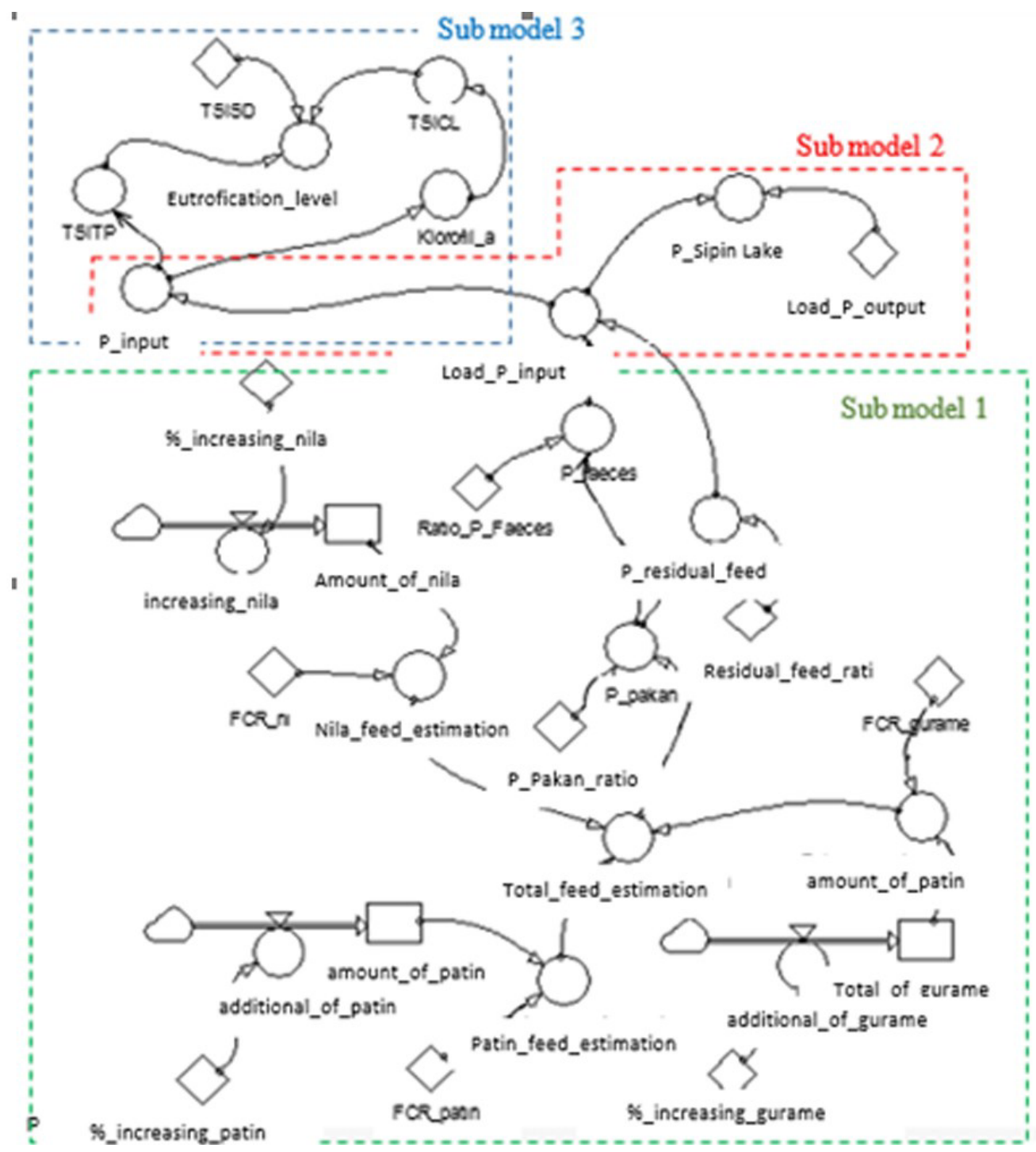

Fig. 3. Sipin Lake trophic status modelling

2. Application of 'pelet' (food) additive on fish feeding to break down the phytic acid. Phytic acid is a compound in fish feces. It will turn phosphate to the water and enrich phosphate concentration. Pelet additive usually used is Ronozyme-P with the application of $0.1 \mathrm{gr}$ in $46.42 \mathrm{gr}$ fish meal, $22 \mathrm{gr}$ rebon flour, and 20.58 gr lamtoro seed flour, it will reduce $0.29 \%$ phytic acid content in fish feces [9]. It is estimated that phosphate enrichment, total phosphate concentration and trophic status of the Lake are also reduced as shown in Figure 6. Figure 6 shows that application of food additive also increases of phosphate enrichment, total phosphate concentration and the trophic status of the Lake. However, all those parameters will be lowered since nothing to in the Lake system. The total phosphate concentration, phosphate enrichment would be $0.16 \%$ and $0.41 \%$, respectively. The trophic status is still eutrophic level.

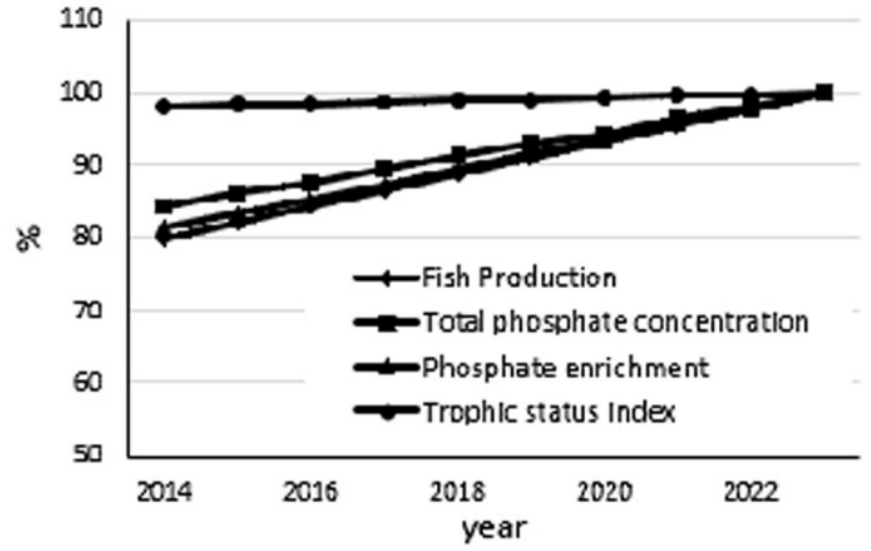

Fig. 6. Sipin Lake estimation condition by applying food additive

3. Reduction of phosphate from river streams. Phosphate in upstream of Sipin Lake probably comes from community activity using detergent, agricultural and farming activities. Sodium tripolyphosphate 
4. content in detergent increases phosphate enrichment in lake water up to $20-30 \%$ [10]. If this policy applies in Sipin Lake the reduction of total phosphate concentration and phosphate enrichment is shown in Figure 7.

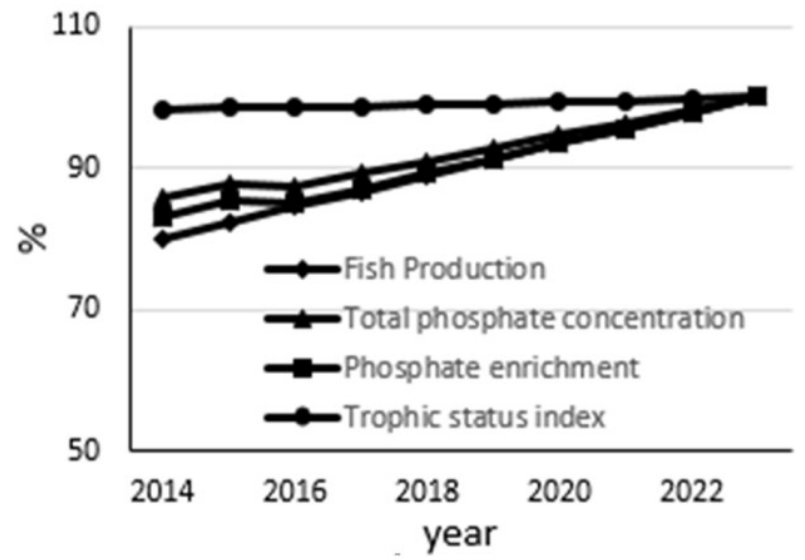

Fig. 7. Sipin Lake estimation condition since no detergent discharge into upstream river

Figure 7 shows that total phosphate concentration is reduced $0.34 \%$ in 2015 . After 8 years total phosphate concentration and phosphate enrichment will be $1.8 \%$ and $2.5 \%$, respectively. However, it is lower than if the system does not enforce anything.

\section{Conclusion}

Floating fishery net in Sipin Lake has triggered of increasing phosphate concentration in the lake. Trophic status index of the Lake is at eutrophic level. The increase of phosphate and trophic status of Sipin Lake has been identified by TSI Carlson method, there is estimated that within next 10 years, there is an increase of phosphate and total phosphate concentration of $18.94 \%$ and $15.64 \%$, respectively and trophic status of the Lake is at eutrophic level. From the simulation, application of double floating fishery net is able to reduce total phosphate concentration and the risk of eutrophication in the lake higher than other policies. So, using double fishery net is a recommendation for the government to anticipate the future condition.

\section{References}

1. L. Cargnelli and M. Doyle. Lake Erie Bi-national Nutrient Management Strategy. Canada: Lakewide Management Plan. 3-5 (2011)

2. W. Gunawan, Zahidah and D. Mulyanti. Model Eutrofikasi untuk Merancang Kebijakan Pengelolaan Waduk yang Berkelanjutan Melalui Pendekatan Sistem Dinamis. Bandung: Faculty of Fisheries and Marine Science Padjajaran University. 1-18 (2007)

3. Dinas Pertanian, Peternakan, Perikanan dan Kehutanan. Profil Perikanan Budidaya Kota Jambi (2014).

4. Badan Lingkungan Hidup Daerah. Status Lingkungan Hidup Daerah (2014).

5. M. Everard. Taking a system-oriented view of phosphorus enrichment in fresh waters- A System-Oriented View of Phosphorus Enrichment. England: Gloucestershire GL50 1QB 35-54 (2011)

6. T.S.Mamatha, M.R.Nandini, T.N.Parinitha, U.Umesha, P.Tuppar, B.M.Kumar and B.M.Krisna. Water quality monitoring and trophic status classification of Karanji Lake Mysore J. Current Engineering and Technology ISSN 2277-410, 43-48 (2013)

7. Lukman. Evaluasi Keseimbangan Fosfat di Danau Toba. Jakarta: Prosiding Seminar Nasional Limnologi, VI, 429. 430 (2012)

8. Rustadi. Eutrofikasi nitrogen dan fosfat serta pengendaliannya dengan perikanan di Waduk Sermo J. Manusia dan Lingkungan, 16, 176-186 (2009)

9. D. Rachmawati and J. Hutabarat. Efek Ronozyme P dalam pakan buatan terhadap pemanfaatan pakan dan pertumbuhan ikan kerapu macan (Epinephelus fuscoguttatus) J. Ilmu Kelautan, 11, 193-200 (2006)

10. H. Horth, E. Glennie, L.J. Davis, P. Jones and O. Tortolea. Recommendation for the Reduction of Phosphorous in Detergents. UK: WRc plc, 15-20 (2006) 